\title{
KOSZTY PRACY - STUDIUM PRZYPADKU JEDNOSTKI BUDŻETOWEJ
}

\author{
Anna Wasilewska \\ Katedra Finansów \\ Szkoła Główna Gospodarstwa Wiejskiego w Warszawie
}

Monika Grajber

\begin{abstract}
Abstrakt. Głównym wydatkiem jednostki budżetowej są koszty związane z zatrudnieniem pracowników, którymi w oświatowej jednostce budżetowej są nauczyciele oraz pracownicy administracji i obsługi. Podstawowym składnikiem kosztów pracy obu grup pracowników jest wynagrodzenie brutto, które jest regulowane innymi aktami prawnymi (ustawą o Karcie Nauczyciela i ustawą o pracownikach samorządowych), co powoduje różnice w ich poziomie. Celem badań było określenie poziomu i struktury kosztów pracy wynikających z zatrudnienia pracowników w jednostce budżetowej, z uwzględnieniem nauczycieli oraz pracowników niepedagogicznych. Materiał empiryczny stanowiły dane i informacje o działalności przedszkola publicznego w latach 2013-2015.
\end{abstract}

Słowa kluczowe: przedszkole, poziom i struktura kosztów pracy, nauczyciele, pracownicy niepedagogiczni

\section{WSTĘP}

Jednostki budżetowe są podmiotami sektora finansów publicznych. Ich wydatki są znacznie wyższe niż przychody, jednakże ze względu na rolę jaką pełnią w systemie społeczno-gospodarczym ich działalność jest niezbędna. Jednostkami budżetowymi są np. przedszkola, szkoły i urzędy gmin. Podmioty te środki pieniężne potrzebne do sfinansowania prowadzonej działalności otrzymują z budżetu państwa lub jednostek samorządu terytorialnego, a w przypadku osiągania do- 
chodów jednostki te mają obowiązek przekazania ich do budżetu państwa bądź jednostki samorządowej.

Głównym wydatkiem jednostek budżetowych są koszty związane z zatrudnieniem pracowników. W oświatowej jednostce budżetowej są nimi nauczyciele oraz pracownicy administracji i obsługi. Wynagrodzenie brutto pracowników z tych grup jest regulowane innymi aktami prawnymi. W przypadku nauczycieli płaca zasadnicza, wysokość odprawy oraz dodatku za wysługę lat jest regulowana ustawą o Karcie Nauczyciela ${ }^{1}$, natomiast te same składniki wynagrodzenia w przypadku pracowników administracji i obsługi są regulowane ustawą o pracownikach samorządowych ${ }^{2}$. Ustawy te nakładają obowiązek określenia wysokości niektórych dodatków do wynagrodzenia przez jednostkę założycielską w regulaminach pracy lub stosownymi uchwałami. dzięki czemu występują rozbieżności w naliczaniu wynagrodzeń brutto oraz dodatków do nich.

Koszty pracy stanowią istotną kategorię kosztów dla każdego pracodawcy, który zatrudniając pracownika oprócz wynagrodzenia za pracę, musi dodatkowo ponosić szereg innych kosztów wynikających z przepisów prawa. Należą do nich składki na ubezpieczenia społeczne, na Fundusz Pracy, koszty BHP, odpis na Zakładowy Fundusz Świadczeń Socjalnych, szkolenia oraz podróże służbowe. Badania przeprowadzono w latach 2013-2015.

Celem badań było określenie poziomu i struktury kosztów pracy wynikających z zatrudnienia pracowników w jednostce budżetowej, z uwzględnieniem nauczycieli oraz pracowników niepedagogicznych.

\section{METODY BADAŃ}

Badania przeprowadzono w przedszkolu, które obecnie jest jedynym publicznym przedszkolem w szesnastotysięcznym mieście położonym około $35 \mathrm{~km}$ od Warszawy $^{3}$. Nadzór nad jego działaniem, jako placówki oświatowej sprawuje $\mathrm{Ku}$ ratorium Oświaty w Warszawie. Celem jego działalności jest przede wszystkim zapewnienie opieki dzieciom oraz kształtowanie ich rozwoju wczesnoszkolnego. Materiał empiryczny stanowiły dane i informacje o działalności przedszkola w latach 2013-2015.

Przedszkole jako jednostka budżetowa jest jednostką sektora finansów publicznych, która nie posiada osobowości prawnej [Winiarska 2011, s. 677-688]. Placówka połączona jest z budżetem gminy metodą budżetowania brutto, czyli

\footnotetext{
${ }^{1}$ Ustawa z dnia 26 stycznia 1982 r. - Karta Nauczyciela [Dz. U. $1982 \mathrm{nr} 3$ poz. 19].

${ }^{2}$ Ustawa z dnia 21 listopada 2008 r. o pracownikach samorządowych [Dz. U. $2008 \mathrm{nr}$ 223, poz. 1458].

${ }^{3}$ Przedszkole powstało w 1970 roku jako jedno z pięciu publicznych przedszkoli.
} 
wydatki przedszkola są pokrywane bezpośrednio przez jednostkę założycielską (gminę), natomiast uzyskiwane przez przedszkole dochody są odprowadzane bezpośrednio na specjalny rachunek bankowy jednostki założycielskiej. Oznacza to, że w przypadku uzyskania dochodów w postaci opłat za przedszkole jednostka nie może ich przeznaczyć bezpośrednio na wypłatę wynagrodzeń dla pracowników czy zakup podstawowych materiałów niezbędnych do prowadzenia działalności [Pietrzak, Polański, Woźniak 2008, s. 59].

Wyjątkiem od zasady budżetowania brutto są dochody własne jednostek budżetowych, które prowadzą działalność określoną w ustawie o systemie oświaty. Dochody własne przedszkole musi odprowadzać na specjalny rachunek bankowy [Gorgol, Smoleń 2012, s. 1003]. Katalog dochodów własnych oraz ich przeznaczenie ustalony jest w uchwale Rady Miasta, w którym funkcjonuje przedszkole. Są nimi np. dochody pochodzące z dzierżawy składników majątku i wyposażenia, odsetek od środków zgromadzonych na rachunku bankowym przedszkola, czynszu z wynajmu. Środki finansowe pochodzące z dochodów własnych mogą być przeznaczone na wydatki związane z prowadzeniem podstawowej działalności przedszkola, remonty, opłaty bankowe za prowadzenie rachunku bankowego, zakupy środków trwałych itp. Środki te nie mogą być wydatkowane na wynagrodzenia pracowników4 ${ }^{4}$ Przedszkole w latach 2013-2015 nie uzyskiwało dochodów własnych.

Koszy pracy stanowią ważny element kosztów operacyjnych, jakie ponosi przedsiębiorstwo. W literaturze jest wiele definicji kosztów pracy. Po raz pierwszy zostały zdefiniowane w 1925 roku przez Leitnera, według którego koszty pracy obejmują nie tylko wynagrodzenia faktycznie wypłacane pracownikowi ale również wydatki związane z opłaceniem składek na ubezpieczenia chorobowe i wypadkowe, podnoszeniem kwalifikacji oraz odzieżą roboczą [Kowalska 2015, s. 219-231].

W Polsce definicja kosztów pracy została wprowadzona przez Halamę w 1962 roku. Twierdził on, że do kosztów tych należy zaliczyć wszystkie koszty jakie pracodawca ponosi z tytułu zatrudnienia pracownika [Latusek 2004, s. 45-57]. Inaczej definiuje koszty pracy J. Wiktor, według którego wyrażają one sumę płac i pozapłacowych kosztów związanych z pozyskiwaniem, utrzymywaniem, doskonaleniem i wykorzystywaniem zasobów pracy, występujących w rachunku kosztów i wyników przedsiębiorstwa [Wiktor 1991 s. 14]. Podobną definicję kosztów pracy przyjęto w badaniach GUS. Zgodnie z nią składnikami kosztów pracy są:

1) wynagrodzenie brutto, $w$ tym dodatkowe wynagrodzenie roczne wypłacane pracownikom samorządowym,

2) składki na ubezpieczenia emerytalne, rentowe, wypadkowe w części obciążającej pracodawcę,

\footnotetext{
${ }^{4}$ Ustawa z dnia 27 sierpnia 2009 r. o finansach publicznych, art. 11 [Dz.U. $2009 \mathrm{Nr} 157$ poz. 1240].

${ }^{5}$ Koszty pracy w gospodarce w 2012 roku, Główny Urząd Statystyczny, Warszawa 2013.
} 
3) składki na Fundusz Pracy i Państwowy Fundusz Rehabilitacji Osób Niepełnosprawnych,

4) odpis na Zakładowy Fundusz Świadczeń Socjalnych,

5) koszty związane z bezpieczeństwem i higieną pracy,

6) koszty podnoszenia kwalifikacji zawodowych oraz przekwalifikowania kadr tj. koszty szkoleń, delegacji służbowych, dofinansowanie do studiów,

7) inne, np. wydatki na rekrutacje, dojazdy pracowników do miejsca pracy.

Definicja ta została przyjęta na potrzeby pracy.

\section{WYNIKI BADAŃ}

W 2013 roku w przedszkolu pracowało 68 pracowników, wśród nich 31 pracowników niepedagogicznych (pracownicy administracji i obsługi) i 37 nauczycieli. W kolejnych latach liczba pracowników niepedagogicznych zmalała do 28 w 2015 roku, natomiast liczba nauczycieli wzrosła do 40. Na rysunku 1 przedstawiono strukturę organizacyjną przedszkola. W nawiasach podano liczbę pracowników zajmujących podane stanowiska w 2016 roku.

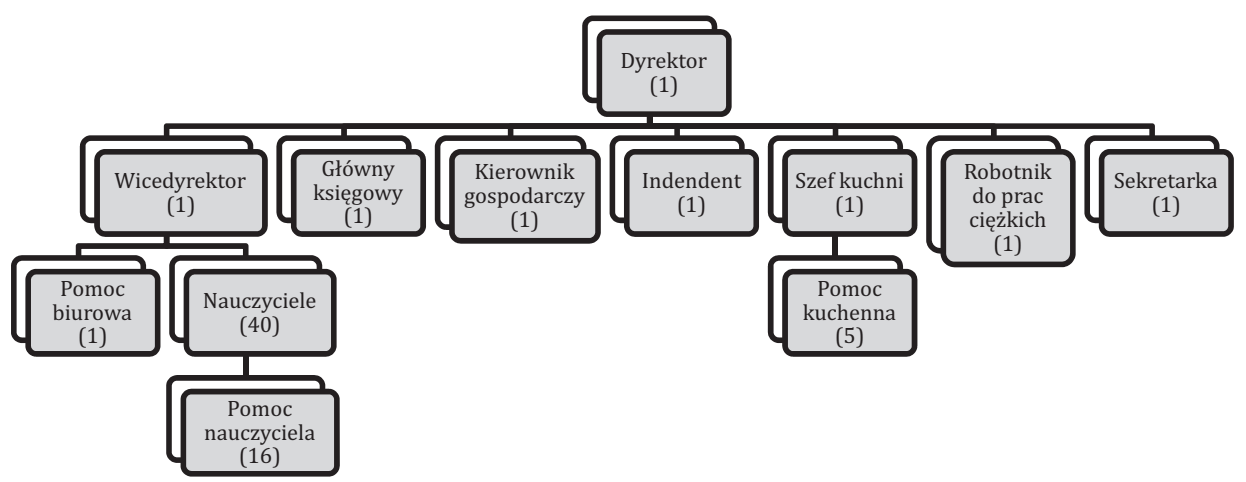

RYSUNEK 1. Struktura organizacyjna przedszkola

Źródło: Opracowanie własne na podstawie danych udostępnionych przez jednostkę.

W badanym okresie na jednego pracownika niepedagogicznego przypadało 14 dzieci. Liczba dzieci przypadająca na 1 nauczyciela zmalała, z 12 w 2013 roku do 10 w 2015 roku. Zmiana wynikała ze wzrostu liczby nauczycieli przy jednoczesnym spadku liczby dzieci (tabela 1 ).

W latach 2013-2015 koszty funkcjonowania przedszkola wynosiły 4165,6$-4395,2$ tys. zł, w porównaniu do 2013 roku wzrosły o 229,6 tys. zł. W zależności od roku od 69,1 do 70,4\% kosztów działalności operacyjnej przedszkola stanowiły koszty pracy. 
TABELA 1. Koszty pracy oraz ich udział w kosztach funkcjonowania przedszkola

\begin{tabular}{|c|c|c|c|}
\hline Lata & $\begin{array}{c}\text { Koszty działalności operacyjnej } \\
\text { (tys. zł) }\end{array}$ & $\begin{array}{c}\text { Koszty pracy } \\
\text { (tys. zł) }\end{array}$ & $\begin{array}{c}\text { Udział kosztów pracy w kosztach } \\
\text { działalności operacyjnej (\%) }\end{array}$ \\
\hline 2013 & 4165,6 & 2877,3 & 69,1 \\
\hline 2014 & 4372,2 & 3070,5 & 70,2 \\
\hline 2015 & 4395,2 & 3094,4 & 70,4 \\
\hline
\end{tabular}

Źródło: opracowanie własne na podstawie danych udostępnionych przez jednostkę.

W tabeli 2 przedstawiono poziom i strukturę kosztów pracy w przedszkolu. W ich skład wchodzą wynagrodzenia brutto, składki emerytalne, rentowe, wypadkowe, składki na Fundusz Pracy, odpis na ZFŚS, koszty związane z bezpieczeństwem i higieną pracy, a także koszty szkoleń i podróży służbowych.

TABELA 2. Poziom i struktura kosztów pracy w przedszkolu

\begin{tabular}{|l|c|c|c|c|c|c|}
\hline \multirow{2}{*}{ Wyszczególnienie } & \multicolumn{2}{|c|}{2013} & \multicolumn{2}{c|}{2014} & \multicolumn{2}{c|}{2015} \\
\cline { 2 - 7 } & tys. zł & $\%$ & tys. zł & $\%$ & tys. zł & $\%$ \\
\hline Wynagrodzenia brutto & 2296,1 & 79,8 & 2447,2 & 79,7 & 2478,9 & 80,1 \\
\hline Składki na ubezpieczenia społeczne & 383,0 & 13,3 & 410,8 & 13,4 & 408,5 & 13,2 \\
\hline Fundusz Pracy & 46,1 & 1,6 & 47,4 & 1,5 & 46,4 & 1,5 \\
\hline Koszty BHP & 5,3 & 0,2 & 6,0 & 0,2 & 2,0 & 0,1 \\
\hline Odpis ZFŚS & 130,7 & 4,5 & 142,1 & 4,6 & 142,4 & 4,6 \\
\hline Inne koszty pracy & 16,1 & 0,6 & 17,1 & 0,6 & 16,2 & 0,5 \\
\hline Szkolenia & 8,6 & 0,3 & 9,4 & 0,3 & 11,5 & 0,4 \\
\hline Podróże służbowe & 7,5 & 0,3 & 7,7 & 0,3 & 4,7 & 0,2 \\
\hline Koszty pracy razem & 2877,3 & 100,0 & 3070,5 & 100,0 & 3094,4 & 100,0 \\
\hline
\end{tabular}

Źródło: opracowanie własne na podstawie danych udostępnionych przez jednostkę.

W strukturze kosztów pracy dominowały wynagrodzenia brutto, ich udział w badanym okresie wynosił 79,7-80,1\%. W latach 2013-2015 koszty z tego tytułu wzrosły nominalnie o 182,8 tys. zł. Od 13,2 do 13,4\% kosztów pracy stanowiły ubezpieczenia społeczne, ich poziom wzrósł z 383 tys. zł w 2013 roku do 408,5 tys. zł w 2015 roku. Znaczną część kosztów pracy stanowił odpis na ZFŚS (4,5-4,6\%), a także składka na Fundusz Pracy (1,5-1,6\%). Odpis na Zakładowy Fundusz Świadczeń Socjalnych w stosunku do 2013 roku wzrósł o 11,7 tys. zł, wynosząc w 2015 roku 142,4 tys. zł, natomiast koszty z tytułu składki na Fundusz Pracy w zasadzie nie uległy zmianie. Udział pozostałych elementów kosztów pracy był nieznaczny. W badanych latach stanowiły one $0,1-0,4 \%$ kosztów pracy. Największe zmiany miały miejsce w zakresie kosztów związanych $\mathrm{z}$ bezpieczeństwem i higieną pracy, poziom tych kosztów był jednak niewielki (2-6 tys. zł). Wydatki na szkolenia oraz podróże służbowe wynosiły odpowiednio $8,6-11,5$ tys. zł oraz 4,7-7,7 tys. zł. 
Obciążenie działalności przedszkola kosztami pracy było zróżnicowane w przypadku nauczycieli i pracowników niepedagogicznych (tabela 3, rys. 2).

$\mathrm{W}$ każdym $\mathrm{z}$ badanych lat roczny koszt zatrudnienia nauczyciela był wyższy niż koszt zatrudnienia pracownika niepedagogicznego. Przyczyną było przede wszystkim zróżnicowanie poziomu wynagrodzenia brutto. W przypadku nauczyciela wynosiło ono 40565,6-43 637,6 zł, stanowiąc 78,2\% kosztów pracy. Wynagrodzenie brutto pracownika administracji i obsługi kształtowało się na poziomie 29 462,6 zł - 34 097,4 zł. Udział tej kategorii w kosztach pracy wynosił średnio

TABELA 3. Roczne koszty pracy w przeliczeniu na pełny etat nauczycieli oraz pracowników administracji i obsługi (zł/rok)

\begin{tabular}{|l|c|c|c|c|c|c|}
\hline \multirow{2}{*}{ Wyszczególnienie } & \multicolumn{3}{|c|}{ Koszty pracy nauczycieli } & \multicolumn{3}{c|}{$\begin{array}{c}\text { Koszty pracy pracowników } \\
\text { niepedagogicznych }\end{array}$} \\
\cline { 2 - 8 } & 2013 & 2014 & 2015 & 2013 & 2014 & 2015 \\
\hline Wynagrodzenia brutto & 43637,6 & 40802,4 & 40565,6 & 29462,6 & 31867,7 & 34097,4 \\
\hline $\begin{array}{l}\text { Składki na ubezpieczenia } \\
\text { społeczne }\end{array}$ & 7501,3 & 7013,9 & 6973,2 & 4686,3 & 5148,0 & 5230,8 \\
\hline Fundusz Pracy & 1069,1 & 999,7 & 993,9 & 395,8 & 360,8 & 324,4 \\
\hline Koszty BHP & 80,3 & 70,0 & 12,2 & 89,6 & 114,5 & 54,3 \\
\hline Odpis ZFŚS & 2991,4 & 2913,7 & 2893,5 & 1159,6 & 1186,7 & 1201,2 \\
\hline Szkolenia & 251,1 & 251,5 & 266,1 & 20,6 & 7,0 & 54,6 \\
\hline Podróże służbowe & 228,6 & 201,8 & 122,1 & 7,8 & 10,1 & 4,0 \\
\hline Koszty pracy razem & 55759,3 & 52252,9 & 51826,5 & 35822,3 & 38694,8 & 40966,9 \\
\hline
\end{tabular}

Źródło: opracowanie własne na podstawie danych udostępnionych przez jednostkę.

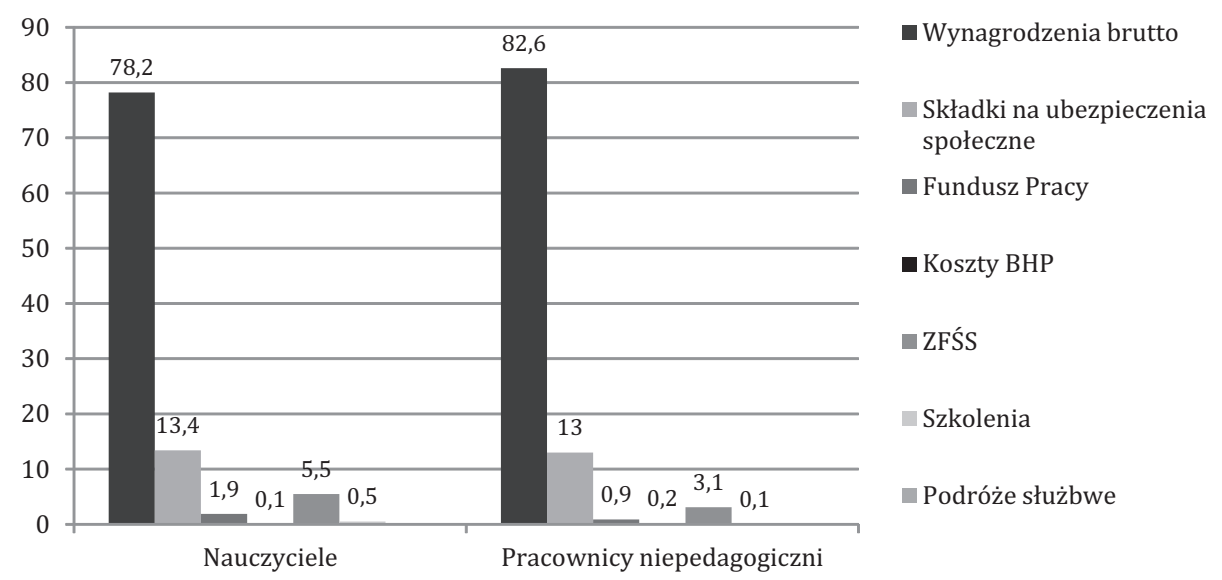

RYSUNEK 2. Elementy kosztów pracy nauczycieli i pracowników niepedagogicznych, wartości średnie za lata 2013-2015 (\%)

Źródło: opracowanie własne na podstawie danych udostępnionych przez jednostkę. 
82,6\%. W latach 2013-2015 wynagrodzenie nauczyciela zmalało o 3072 zł, natomiast pracownika niepedagogicznego wzrosło o 4 634,8 zł. Przyczyną zmian wynagrodzeń w przypadku nauczycieli było niższe uposażenie nowo przyjętych pracowników, którzy dodatkowo ze względu na staż pracy nie uzyskiwali dodatku za wysługę lat. Wzrost wynagrodzeń pracowników niepedagogicznych był spowodowały podwyżkami płac w tej grupie zawodowej.

Z uwagi na fakt, że podstawą obliczania składek na ubezpieczenie społeczne oraz Fundusz Pracy jest wynagrodzenie brutto pracownika, koszt obciążenia pracodawcy z tych tytułów był wyższy w przypadku nauczyciela. Udział składek na ubezpieczenie społeczne w kosztach pracy zarówno nauczyciela, jak i pracownika niepedagogicznego był w zasadzie jednakowy (13-13,4\%), natomiast składka na Fundusz Pracy stanowiła 1,9\% kosztów pracy nauczyciela, a 0,8-1,1 (średnio 0,9\%) pracownika niepedagogicznego. Składka odprowadzana za pracownika administracji i obsługi z roku na rok malała, mimo że wynagrodzenie brutto, które jest podstawą do naliczenia tej składki wzrastało. Przyczyną był brak konieczności odprowadzania składek na Fundusz Pracy od ponad połowy pracowników administracji i obsługi wynikający z ich wieku ${ }^{6}$. Również udział tej składki w kosztach pracy pracowników niepedagogicznych w badanym okresie wykazywał tendencją spadkową.

Koszty szkoleń nauczycieli w latach 2013-2015 kształtowały się na poziomie od 251,1 zł do 266,1 zł, natomiast pracownika administracji i obsługi od 7 zł do 54,6 zł. Szkolenia dla pracowników niepedagogicznych dotyczyły głównie osób zatrudnionych na stanowisku księgowego, sekretarki, intendenta oraz szefa kuchni, natomiast w przedszkolu najwięcej pracowników niepedagogicznych zatrudnionych jest na stanowisku pomocy nauczyciela, a oni nie odbywają szkoleń, co tłumaczy niską wysokość kosztów szkolenia dla pracowników z tej grupy.

Różnica w wysokości odpisu na Zakładowy Fundusz Świadczeń Socjalnych wynika z innego sposobu obliczania odpisu na jednego nauczyciela oraz pracownika administracji obsługi ${ }^{7}$. Koszt zatrudnienia nauczyciela we wszystkich kate-

\footnotetext{
${ }^{6}$ Składka na Fundusz Pracy stanowi 2,45\% podstawy wymiaru, czyli wynagrodzenia brutto. Pracodawca nie ma obowiązku odprowadzania tych składek m.in. w sytuacji, gdy zatrudniona kobieta ukończyła 55 lat, a mężczyzna 60 lat.

7 Odpis na ZFŚS w przypadku pracownika niepedagogicznego zatrudnionego w normalnych warunkach pracy (pracownicy przedszkola) stanowi 37,5\% przeciętnego wynagrodzenia miesięcznego $\mathrm{w}$ gospodarce narodowej $\mathrm{w}$ roku poprzednim lub $\mathrm{w}$ drugim półroczu roku poprzedniego, jeżeli przeciętne wynagrodzenie $\mathrm{z}$ tego okresu stanowiło kwotę wyższą. Przeciętne wynagrodzenie w 2017 roku wynosiło 3 161,77 zł, czyli tworzony odpis 37,5\% kwoty 3161,77 = 1185,66. Odpis na Zakładowy Fundusz Świadczeń Socjalnych według ustawy o Karcie Nauczyciela jest natomiast tworzony jako iloczyn przeciętnego planowanego zatrudnienia w przeliczeniu na pełne etaty oraz $110 \%$ kwoty bazowej dla nauczycieli obowiązującej w danym roku. Wysokość kwoty bazowej potrzebnej do ustalenia odpisu wynosi od 2012 roku 2618,1 zł. Oznacza to, że za każdego
} 
goriach z wyjątkiem wydatków na BHP był wyższy niż pracownika administracji i obsługi. Główne koszty związane z wydatkami na BHP pracowników niepedagogicznych stanowią fartuchy do pracy w kuchni, obuwie i specjalna odzież ochronna do pracy na zewnątrz.

W tabeli 4 przedstawiono wybrane wskaźniki kosztów pracy $^{8} \mathrm{z}$ uwzględnieniem nauczycieli i pracowników niepedagogicznych.

TABELA 4. Wybrane wskaźniki kosztów pracy

\begin{tabular}{|l|c|c|c|c|c|c|}
\hline \multirow{2}{*}{ Wyszczególnienie } & \multicolumn{3}{|c|}{ Nauczyciel } & \multicolumn{3}{c|}{ Pracownik niepedagogiczny } \\
\cline { 2 - 7 } & 2013 & 2014 & 2015 & 2013 & 2014 & 2015 \\
\hline $\begin{array}{l}\text { Miesięczny koszty pracy } \\
\text { w przeliczeniu na jeden etat (tys. zł) }\end{array}$ & 4,29 & 4,02 & 3,98 & 2,76 & 2,98 & 3,15 \\
\hline $\begin{array}{l}\text { Miesięczne wynagrodzenie netto } \\
\text { w przeliczeniu na jeden etat (tys. zł) }\end{array}$ & 2,41 & 2,25 & 2,24 & 1,65 & 1,77 & 1,89 \\
\hline $\begin{array}{l}\text { Udział wynagrodzenia netto } \\
\text { w kosztach pracy (\%) }\end{array}$ & 56,2 & 56,0 & 56,3 & 59,8 & 59,4 & 60,0 \\
\hline
\end{tabular}

Źródło: opracowanie własne na podstawie danych udostępnionych przez jednostkę.

W badanym okresie miesięczny koszt pracy nauczyciela zatrudnionego w przedszkolu malał, co związane było ze spadkiem wynagrodzeń brutto tej grupy pracowników. W 2015 koszt ten wynosił 3,98 tys. zł, w porównaniu do 2013 roku zmalał o 0,31 tys. zł. W przypadku pracowników administracji i obsługi miesięczny koszt pracy w badanym okresie wzrósł, przyczyną zmian był wzrost wynagrodzeń brutto pracowników tej grupy, które stanowiły 82,6\% kosztów pracy mając największy wpływ na kształtowanie się kosztów pracy. Koszty zatrudnienia pracowników niepedagogicznych w latach 2013-2015 wzrosły z 2,76 tys. zł do 3,15 tys. zł. Konsekwencją różnic w kosztach pracy, których głównym elementem było wynagrodzenie brutto były zmiany kwot wypłacanych pracownikom za wykonaną pracę. Wynagrodzenie netto nauczyciela w badanym okresie zmalało z 2,41 do 2,24 tys. zł, natomiast pracownika niepedagogicznego z 1,65 tys. zł do 1,89 tys. zł.

pracownika zatrudnionego na pełny etat pracodawca jest zobowiązany utworzyć odpis na ZFŚS w wysokości 2 879,91 zł [110\% kwoty 2618,10 zł]. Pracodawca musi również utworzyć odpis za nauczycieli, którzy przeszli na emeryturę bądź rentę lub pobierają świadczenie kompensacyjne w wysokości 5\% pobieranych przez nich świadczeń emerytalnych, rentowych lub kompensacyjnych [Ustawa z dnia 26 stycznia 1982 r. - Karta Nauczyciela, Dz. U. $1982 \mathrm{nr} 3$ poz. 19].

${ }^{8}$ Wskaźniki kosztów pracy są wykorzystywane w controlingu personalnym do porównania kosztochłonności czynnika pracy zarówno w kolejnych latach, jak i poszczególnych stanowisk. Im większe znaczenie dla działalności firmy mają zasoby ludzkie tym wskaźnik ten będzie wyższy [Bernais, Ingram 2005, s. 99]. 
Stosunek wynagrodzenia netto nauczycieli do kosztów ich zatrudnienia kształtował się w latach 2013-2015 na poziomie 56-56,3\% i był niższy od tej samej relacji liczonej dla pracownika administracji i obsługi. Udział wynagrodzenia netto w kosztach pracy pracowników niepedagogicznych wynosił 59,4-60\%. Tak więc wynagrodzenie netto, które otrzymuje do dyspozycji pracownik niepedagogiczny stanowi większą część kosztów pracy związanych z jego zatrudnieniem niż nauczyciela, co oznacza ze pracodawca ponosi niższe koszy pracy zatrudniając pracownika niepedagogicznego niż nauczyciela.

W tabeli 5 przedstawiono wybrane informacje dotyczące kosztów w badanym przedszkolu.

TABELA 5. Wybrane informacje dotyczące kosztów oraz opłat z tytułu wyżywienia i pobytu dzieci w przedszkolu (tys. zł/rok)

\begin{tabular}{|l|c|c|c|}
\hline \multirow{2}{*}{ Wyszczególnienie } & \multicolumn{3}{|c|}{ Lata } \\
\cline { 2 - 4 } & 2013 & 2014 & 2015 \\
\hline Koszty działalności przedszkola w przeliczeniu na jedno dziecko & 9,7 & 10,2 & 11,3 \\
\hline Koszt pracy w przeliczeniu na jedno dziecko & 6,7 & 7,1 & 7,9 \\
\hline Opłata za wyżywienie i pobyt dziecka w przedszkolu & 1,8 & 1,5 & 1,8 \\
\hline
\end{tabular}

Źródło: opracowanie własne na podstawie danych udostępnionych przez jednostkę.

W badanym okresie koszty działalności przedszkola w przeliczeniu na jedno dziecko wykazywały tendencję wzrostową, wynosząc od 9,7 do 11,3 tys. zł. Ta sama tendencja dotyczyła kosztów pracy, które w 2013 roku w przeliczeniu na wychowanka wynosiły 6,7 tys. zł, natomiast w 2015 roku 7,9 tys. zł. Przyczyną zmian obu wskaźników był przede wszystkim wzrost wynagrodzeń pracowników niepedagogicznych przedszkola, liczba dzieci w badanym okresie zmalała. Opłata za pobyt oraz wyżywienie dziecka w przedszkolu w latach 2013-2015 wynosiła 1,5-1,8 tys. zł, pokrywając od 15 do 18\% kosztów działalności przedszkola. Poziom wskaźnika wskazuje na duży współudział państwa w wychowaniu przedszkolnym dzieci.

\section{PODSUMOWANIE I WNIOSKI}

Podsumowując przeprowadzone badania należy stwierdzić, że:

1) Koszty pracy stanowiły około $70 \%$ kosztów działalności przedszkola, które w latach 2013-2015 wzrosły z 2,9 do 3,1mln zł. Przyczyną zmiany był wzrost wynagrodzeń brutto pracowników administracji i obsługi z 29,5 do 34,1 tys. zł. Roczne koszty pracy nauczycieli zmalały (z 43,6 do 40,6 tys. zł).

2) Koszty pracy w głównej mierze kształtowane były przez wynagrodzenie brutto i składki na ubezpieczenie społeczne. Wynagrodzenia brutto stanowiły 
średnio 78,2\% kosztów pracy nauczycieli, a 82,6\% pracowników niepedagogicznych. Udział składek na ubezpieczenia społeczne nie był zróżnicowany (13-13,4\%). Znaczącą część kosztów pracy stanowił odpis na ZFŚŚ (5,5\% w strukturze kosztów pracy nauczycieli, 3,1\% pracowników niepedagogicznych). Znaczenie pozostałych elementów składowych kosztów pracy było niewielkie, stanowiły one do 2\% kosztów pracy w badanym okresie. Jedynym składnikiem kosztów pracy, który był wyższy w przypadku pracowników administracji i obsługi było BHP, były to głównie wydatki na fartuchy do pracy w kuchni, obuwie i odzież ochronna do pracy na zewnątrz.

3) Konsekwencją różnic w kosztach pracy, których głównym elementem było wynagrodzenie brutto były zmiany kwot wypłacanych pracownikom za wykonaną pracę. Miesięczne wynagrodzenie netto nauczyciela w badanym okresie zmalało z 2,4 do 2,2 tys. zł, natomiast pracownika niepedagogicznego wzrosło z 1,7 tys. zł do 1,9 tys. zł.

4) Wynagrodzenie netto, które otrzymuje do dyspozycji pracownik niepedagogiczny stanowiło większą część kosztów pracy niż w przypadku nauczyciela, co oznacza ze pracodawca ponosi niższe koszty pracy zatrudniając pracownika niepedagogicznego niż nauczyciela. Relacja wynagrodzenia netto do kosztów pracy w przypadku pracowników niepedagogicznych wynosiła 60\%, natomiast w przypadku nauczycieli kształtowała się na poziomie $56 \%$.

5) Roczne koszty funkcjonowania przedszkola w przeliczeniu na 1 dziecko charakteryzowały się tendencją wzrostową, od 9,7 do 11,3 tys. zł. Koszty pracy w przeliczeniu na jedno dziecko także wzrosły, kształtując się na poziomie 7-8 tys. zł. Przyczyną zmian wskaźnika był wzrost kosztów pracy, głównie za sprawą wynagrodzeń brutto oraz zmniejszenie liczby dzieci uczęszczających do przedszkola. Opłaty za wyżywienie oraz pobyt dziecka w przedszkolu stanowiły niewielką część kosztów funkcjonowania przedszkola, w tym również kosztów pracy. W badanych latach kształtowały się na poziomie 1,5-1,8. Sytuacja ta świadczy o coraz większym udziale gminy w finansowaniu działalności przedszkola.

\section{Spis literatury}

BERNAIS J., INGRAM J. 2005: Controling personalny i koszty pracy, Akademia Ekonomiczna Katowice, Katowice.

GORGOL A., SMOLEŃ P. 2012: Ustawa o finansach publicznych. Komentarz, (red.), Wydawnictwo C.H. Beck Warszawa.

Koszty pracy w gospodarce w 2012 roku, Główny Urząd Statystyczny, Warszawa 2013.

KOWALSKA S. 2015: Koszty pracy w strukturze kosztów działalności wybranej spółki X, Studium przypadku, Zeszyty Naukowe Wyższej Szkoły Handlowej, Zarządzanie nr 3, s. 219-231. 
LATUSEK M. 2004: Koszty pracy - ich klasyfikacja, struktura i pomiar, Zeszyty Naukowe Akademii Ekonomicznej w Krakowie, nr 642, s. 45-57.

PIETRZAK B., POLAŃSKI Z., WOŹNIAK B. 2008: System finansowy w Polsce, (red.), tom 2,Wydawnictwo PWN, Warszawa.

Ustawa z dnia 21 listopada 2008 r. o pracownikach samorządowych [Dz. U. 2008 nr 223, poz. 1458].

Ustawa z dnia 26 stycznia 1982 r. - Karta Nauczyciela [Dz. U. $1982 \mathrm{nr} 3$ poz. 19].

Ustawa z dnia 27 sierpnia 2009 r. o finansach publicznych [Dz.U. z 2009 Nr 157 poz. 1240].

WIKTOR J.W. 1991: Koszty pracy w przedsiębiorstwie, IPiSS, Warszawa.

WINIARSKA K. 2011: Zeszyty Naukowe Uniwersytetu Szczecińskiego, Nr 625 Finanse, Rynki Finansowe, Ubezpieczenia, nr 32, s. 677-688.

\title{
LABOUR COSTS - CASE STUDY OF LOCAL GOVERNMENT BUDGET ENTITY
}

\begin{abstract}
The main expenditures of a budget entity are the costs associated with employing workers, who are teachers, administrators and servants. The basic component of the labor costs of the two groups of workers is gross remuneration, which is regulated by legal acts (Teachers' Charter Act and the Act on Local Government Employees), which causes differences in their level. The purpose of the study was to determine the level and structure of labour costs resulting from the employment of staff in the budget entity, including teachers and non-pedagogical staff. The empirical material consisted of data and information on the activities of public kindergartens in the years 2013-2015.
\end{abstract}

Key word: kindergarten, labour costs level, labour costs structure, teachers, nonpedagogical staff 